\begin{tabular}{|c|c|c|}
\hline & $\begin{array}{l}\text { Bioeduca: Journal of Biology Education } \\
\text { http://iournal.walisongo.ac.id/index.php/bioeduca } \\
\text { ISSN 2714-8009 (print), 2715-7490 (online) }\end{array}$ & BBOEDOOCA \\
\hline WALISONGO & $\begin{array}{c}\text { Volume 3, Nomor 1, Tahun } 2021 \\
\text { Hal. } 60-70\end{array}$ & \\
\hline
\end{tabular}

\title{
Literasi Sains Siswa Kelas IX dengan Implementasi Media Pembelajaran Berbasis eXe Learning Pada Materi Pewarisan Sifat
}

\author{
Noor Eka Febryana ${ }^{1}$, Nurul Septiana ${ }^{2}$, Mukhlis Rohmadi ${ }^{3}$ \\ 1,2,3Tadris Biologi, Institut Agama Islam Negeri Palangka Raya \\ *Email: noorekaf@gmail.com
}

\begin{tabular}{ll}
\hline Informasi Artikel & \multicolumn{1}{c}{ ABSTRAK } \\
\hline Submit: $19-10-2020$ & Literasi sains penting untuk dimiliki siswa karena berpotensi \\
Diterima: $29-03-2021$ & besar dalam mendukung pembangunan sumber daya manusia \\
Dipublikasikan: $31-03-2021$ & yang kompeten dan berkualitas guna menghadapi tantangan era \\
& globalisasi. Rendahnya literasi sains siswa di kelas IX MTs \\
& Muslmat NU Palangka Raya harus diatasi dengan implementasi \\
& media pembelajaran berbasis teknologi seperti eXe Learning. \\
& Penelitian ini nertujuan untuk mengetahui pengaruh \\
& implementasi media eXe Learning terhadap literasi sains siswa. \\
& Metode penelitian ini adalah eksperimen semu dengan desain \\
& Nonequivalent control group. Hasil penelitian ini dapat \\
& menyatakan bahwa terdapat perbedaan pengaruh yang \\
& signifikan pada kemampuan literasi sains siswa kelas IX MTs \\
& Muslimat NU Palangka Raya setelah implementasi media \\
& pembelajaran berbasis eXe Learning materi pewarisan sifat \\
karena diperoleh nilai thitung >ttabel, yaitu nilai thitung sebesar 5,147 \\
dan nilai tabel sebesar 1,665. \\
Kata kunci: eXe Learning; literasi sains; pewarisan sifat.
\end{tabular}

Copyright (O2021, Bioeduca: Journal of Biology Education

\section{PENDAHULUAN}

Pembelajaran Sains di SMP/MTs harus mumpuni dalam menjawab berbagai persoalan dalam perkembangan pesat era globalisasi yang mengharuskan siswa untuk mampu berperan aktif dan bersikap solutif. Pembelajaran hendaknya 
berpedoman pada Standar Nasional Pendidikan. Sesuai dengan Peraturan Menteri Pendidikan dan Kebudayaan Republik Indonesia Nomor 65 Tahun 2013 mengenai standar dalam proses pendidikan dasar maupun menengah, untuk meningkatkan kualitas pendidikan (Sudirgayasa, 2014:2). Diperlukan mekanisme pembelajaran yang mampu mempersiapkan siswa yang berkompetensi baik. Beberapa kompetensi itu diantaranya seperti melek sains dan teknologi, serta mampu berpikir logis dan kritis (Yuliati, 2017:568, Kurnia \& Fathurohman, 2014:43, Arief, 2015:167).

Pesatnya perkembangan teknologi era abad 21 ini sejalan dengan akselerasi globalisasi yang kerap kali mengancam entitas dan jati diri suatu bangsa. Sehingga perlu adanya penguatan guna menghadapi kecaman arus globalisasi. Salah satu caranya adalah dengan penanaman pengetahuan literasi sains yang kuat dalam diri siswa (Mukti, 2018). Literasi sains penting untuk dimiliki siswa karena berpotensi besar dalam mendukung pembangunan sumber daya manusia yang kompeten dan berkualitas guna menghadapi tantangan era globalisasi dan industrialisasi (Nofiana dan Julianto, 2018). Sehingga penting bagi setiap tenaga pendidik untuk menanamkan nilai-nilai penting literasi dalam pembelajaran apapun terutama dalam pembelajaran sains.

Literasi sains merupakan kemampuan untuk dapat menggunakan konsep sains dan keterampilan proses sains. Dengan kemampuan tersebut seseorang mampu untuk menyelesaikan berbagai permasalahan dengan menggunakan pendekatan konsep sains serta memahami interaksi antara sains, teknologi dan masyarakat, termasuk perkembangan sosial dan ekonomi (Odja, \& Payu, 2014:40-41).

Salah satu faktor yang dapat mendukung terciptanya kemampuan literasi sains pada siswa adalah dengan penggunaan media pembelajaran yang tepat dan sesuai (Rohmawati, Widodo, Agustini, 2018). Salah satunya adalah penggunaan media pembelajaran dalam bentuk multimedia. Media pembelajaran berupa multimedia terdiri atas gabungan aspek video, audio, grafis, dan teks. Menurut Rosandi, Tjandrakirana, dan Supardi (2016) Media pembelajaran dalam bentuk multimedia dapat mendukung penguasaan konsep pembelajaran sains menjadi lebih menyenangkan serta bermakna.

Media pembelajaran dalam bentuk multimedia ini salah satunya ada pada aplikasi eXe Learning. Aplikasi eXe Learning merupakan open source yang menggunakan bahasa pemrogragam HTML namun mudah digunakan walau pengguna tidak memahami bahasa pemograman sekalipun (Machril \& Darwin, 2015:97). Selain mudah digunakan dalam pembelajaran, penggunaan media pembelajaran berbasis eXe Learning menurut Lubis dan Napitupulu (2016) juga dapat meningkatkan capaian hasil belajar pada pembelajaran IPA.

Penggunaan eXe Learning dirasa cocok untuk diimplementasikan guna meningkatkan literasi sains siswa serta meningkatkan keterampilan siswa dalam pemanfaatan teknologi sebagai salah satu bentuk persiapan menghadapi revolusi industri 5.0 (Arjunaita, 2020; Kusmana, 2017:35; Andina, 2011:79). Berdasarkan hasil observasi awal dengan pemberian soal literasi sains kepada siswa kelas IX MTs Muslimat NU Palangka Raya diperoleh rata-rata kemampuan literasi sainsnya hanya 
sebesar 50,53\% dalam kategori rendah. Menurut wawancara dengan guru IPA di MTs Muslimat NU Palangka Raya, rendahnya literasi sains siswa ini dikarenakan minimnya media pembelajaran yang digunakan dan metode pembelajaran masih terbatas pada metode teacher-centered saja. Selain itu juga dipaparkan bahwa belum pernah dilakukan integrasi media pembelajaran berbasis teknologi dalam keberlangsungan pembelajaran IPA di MTs Muslimat NU Palangka Raya.

Berdasarkan latar belakang yang telah dipaparkan sebelumnya inilah yang mendasari dilakukannya penelitian ini. Penelitian ini dilakukan dengan tujuan untuk mengetahui kemampuan literasi sains siswa setelah diimplementasikannya pembelajaran menggunakan media eXe Learning pada materi pewarisan sifat kelas IX di MTs Muslimat NU Palangka Raya.

\section{METODE PENELITIAN}

Jenis penelitian ini adalah kuantitatif deskriptif dengan desain penelitian eksperimen semu. Bentuk desain eksperimen semu ini adalah Nonequivalent control group yang menggunakan dua kelompok penelitian yakni kelompok kontrol dan eksperimen (Sugiyono, 2016:77-79). Penelitian ini dilaksanakan di MTs Muslimat NU Palangka Raya pada bulan Oktober - November 2019. Sampel dalam penelitian ini adalah kelas IX A dan IX B tahun ajaran 2019/2020 yang berjumlah 79 orang siswa. Penentuan sampel dilakukan dengan teknik purposive sampling dengan pertimbangan bahwa kedua kelompok yang diambil bersifat homogen.

Variabel independen dalam penelitian ini adalah implementasi media pembelajaran berbasis eXe Learning yang telah divalidasi. Sedangkan variabel dependennya adalah kemampuan literasi sains siswa kelas IX MTs Muslimat NU Palangka Raya.

Teknik pengumpulan data pada penelitian ini menggunakan metode tes dan non tes. Metode tes dilakukan dengan pemberian soal pra-test dan post-test yang telah divalidasi, dianalisis realibilitas, tingkat kesukaran, dan daya beda butir soalnya. Sedangkan metode non tes dilakukan dengan teknik wawancara tak terstruktur dan dokumentasi.

Pembuatan instrumen soal pra-test dan post-test literasi sains didasari pada indikator literasi sains dalam Tabel 1. Soal yang dibuat berupa soal pilihan ganda berjumlah 25 butir soal.

Tabel 1. Indikator Literasi Sains (PISA, 2015)

\begin{tabular}{l}
\hline \multicolumn{1}{c}{ Indikator Literasi Sains Menurut PISA } \\
\hline Proses Sains : \\
a. Menjelaskan fenomena sains \\
b. Menggunakan bukti ilmiah \\
c. Mengidentifikasi pertanyaan ilmiah \\
\hline Konten Sains : \\
Memahami fenomena \\
\hline Konteks Sains : \\
Memecahkan Masalah \\
\hline
\end{tabular}


Skor hasil literasi sains yang telah diperoleh kemudian dikonversikan ke dalam skor dengan nilai maksimum skor 100 dan nilai minimum skor 0 . Kemudian nilai hasil konversi ini akan dikategorikan ke dalam kriteria tertentu untuk mengetahui tingkat kemampuan literasi sains siswa. Kriteria dari literasi sains siswa dikategorikan dalam Tabel 2.

Tabel 2. Kriteria Tingkat Penguasaan Kemampuan Literasi Sains Peserta didik (Ayuningtyas, 2016:38)

\begin{tabular}{cc}
\hline Nilai Konversi & Kriteria \\
\hline $81-100$ & Sangat tinggi \\
$61-80$ & Tinggi \\
$41-60$ & Sedang \\
$21-40$ & Rendah \\
$0-20$ & Sangat rendah \\
\hline
\end{tabular}

Data yang telah diperoleh berupa nilai setelahnya diubah terlebih dulu menurut standar mutlak. Kemudian setelahnya akan dilakukan perbandingan untuk mengetahui tingkat pemahaman siswa dengan uji $\mathrm{N}$-gain. Uji $\mathrm{N}$-gain dilakukan untuk mengetahui besar peningkatan literasi sains setelah dilakukannya implementasi pembelajaran menggunakan media eXe Learning.

Analisis data pada penelitian ini terdiri atas uji pra-hipotesis dan uji hipotesis. Uji pra-hipotesis dilakukan dengan menguji data menggunakan uji normalitas dan uji homogenitas. Uji normalitas bertujuan untuk mengetahui distribusi kenormalan data yang dilakukan dengan menggunakan rumus Lilifors. Sedangkan uji homogenitas bertujuan untuk mengetahui variansi data. Kedua uji ini merupakan uji pra syarat sebelum melakukan uji hipotesis (Sudjana, 2007).

Uji hipotesis dilakukan dengan taraf signifikansi 5\% untuk mengetahui pengaruh implementasi media eXe Learning terhadap literasi sains siswa. Untuk menguji hipotesis ini digunakan uji-t dengan program Microsoft Excel 365 yaitu t-Test: TwoSample Assuming Equal Variances. Kriteria dari pengujian ini dilihat dari hasil thitung

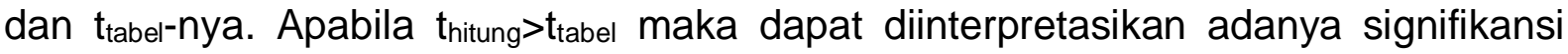
pengaruh implementasi media eXe Learning pada materi pewarisan sifat terhadap kemampuan literasi sains siswa kelas IX MTs Muslimat NU Palangka Raya.

\section{HASIL PENELITIAN DAN PEMBAHASAN}

Hasil pra-test, post-test, dan N-Gain literasi sains siswa pada implementasi media eXe Learning digambarkan pada Tabel 3. Tabel 3 merepresentasikan hasil ratarata pra-test dan post-test yang dianalisis dengan $\mathrm{N}$-gain berada pada kategori sedang pada kelompok eksperimen dan berada pada kategori rendah pada kelompok kontrol.

Tabel 3. Hasil Rata-Rata Pra-test dan Post-test Literasi Sains Kelompok Eksperimen dan Kelompok Kontrol

\begin{tabular}{clllll}
\hline Kelompok Sampel & Pra-test & Post-test & Gain & N-Gain & Kriteria \\
\hline Kelompok Eksperimen & 36,37 & 54,1 & 19,9 & 0,3 & Sedang \\
Kelompok Kontrol & 27,25 & 39,07 & 16,78 & 0,23 & Rendah \\
\hline${ }^{*}$ Keterangan: nilai $(<\mathrm{g}>)>0,7$ (g-tinggi), nilai $0,7(<\mathrm{g}>)$ 0,3 (g-sedang), nilai $(<\mathrm{g}>)<0,3$ (g-rendah)
\end{tabular}


Literasi sains siswa turut dianalisis dari persentase pada tiap indikatornya. Persentase literasi sains siswa pada lima indikator literasi sains terdapat pada Tabel 4. Hasil analisis ini diperoleh dari hasil post-test soal literasi sains siswa. Tabel 4 merepresentasikan bahwa rata-rata kemampuan literasi sains siswa pada kelompok eksperimen sebesar $54,76 \%$ dalam kategori sedang dan kelompok kontrol sebesar $39,67 \%$ dalam kategori rendah.

Tabel 4. Hasil Penilaian Literasi Sains Kelompok Eksperimen dan Kelompok Kontrol Tiap Indikator

\begin{tabular}{llllll}
\hline No & Aspek Penilaian & $\begin{array}{l}\text { Penilaian } \\
\text { Kelompok } \\
\text { Eksperimen } \\
(\%)\end{array}$ & Kriteria & $\begin{array}{l}\text { Penilaian } \\
\text { Kelompok } \\
\text { Kontrol } \\
(\%)\end{array}$ & Kriteria \\
\hline $1 \quad \begin{array}{l}\text { Menjelaskan fenomena } \\
\text { sains }\end{array}$ & $39,38 \%$ & Sedang & $29,49 \%$ & Rendah \\
\hline $\begin{array}{l}\text { Menggunakan bukti } \\
\text { ilmiah }\end{array}$ & $65 \%$ & Tinggi & $38,46 \%$ & Rendah \\
3 & $\begin{array}{l}\text { Mengidentifikasi } \\
\text { pertanyaan ilmiah }\end{array}$ & $70 \%$ & Tinggi & $47,86 \%$ & Sedang \\
4 & Memahami fenomena & $45,94 \%$ & Sedang & $33,33 \%$ & Rendah \\
5 & Memecahkan Masalah & $53,50 \%$ & Sedang & $49,23 \%$ & Sedang \\
\hline Rata-rata & $\mathbf{5 4 , 7 6 \%}$ & Sedang & $\mathbf{3 9 , 6 7 \%}$ & Rendah \\
\hline
\end{tabular}

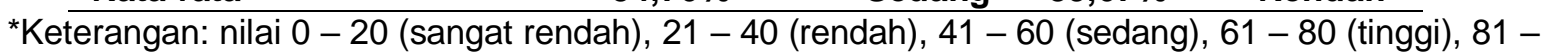
100 (sangat tinggi).

Berdasarkan hasil analisis pada tabel 3 dan 4 kategori kemampuan literasi sains siswa pada kelompok eksperimen berada pada kriteria sedang dan pada kelompok kontrol berada pada kriteria rendah. Adanya peningkatan hasil literasi sains sesudah implementasi media eXe Learning sejalan dengan penelitian yang dilakukan oleh Muzijah, Wati, dan Mahtari (2020).

Indikator tertinggi pada kemampuan literasi sains siswa terdapat pada indikator mengidentifikasi pertanyaan ilmiah sebesar $70 \%$ pada kelompok eksperimen. Hal ini terjadi karena dalam media eXe Learning dilengkapi dengan latihan soal yang bersifat interaktif, dimana siswa dapat langsung mengetahui jawaban yang benar dan salah serta siswa dapat mengetahui akumulasi skor yang diperoleh setelah mengerjakan latihan soal tersebut. Sehingga siswa dapat melakukan latihan soal secara berulangulang untuk meningkatkan pemahamannya. Sejalan dengan penelitian yang dilakukan Wibowo (2020) bahwa multimedia yang interaktif mampu meningkatkan kemampuan self effifacy siswa sehingga ia dapat menggunakan pemahaman konsep sains yang dimiliki dalam menyelesaikan suatu permasalahan secara objektif.

Begitu pula dengan indikator penggunaan bukti ilmiah sebesar $65 \%$ pada kelompok eksperimen. Hal ini didasari karena adanya fitur laboratorium virtual dalam media eXe Learning sehingga mengajak kepada siswa untuk melakukan pengamatan secara objektif guna memecahkan rumusan masalah yang diteliti. Sejalan dengan penelitian yang dilakukan oleh Arisman (2015) bahwa pengamatan yang dilakukan dalam praktikum dapat meningkatkan literasi sains siswa karena mendukung ketercapaian indikator penggunaan bukti ilmiah. Sebab dengan pelaksanaan praktikum mampu menjadikan siswa untuk berpikir secara analitis, kreatif, dan kritis akan suatu permasalahan. 
Pada indikator literasi sains mengenai pemecahan masalah, memahami suatu fenomena, dan menjelaskan suatu fenomena sains pada kelompok eksperimen berada pada kategori sedang. Hal ini didukung dengan adanya media visual berupa teks maupun gambar dan animasi yang ada pada media eXe Learning. Hal ini sejalan dengan penelitian yang dilakukan Risma, Rahmayani, dan Handayani (2019) bahwa media teks memiliki peran penting untuk menjadi dasar penanaman literasi sains. Sebagaimana media eXe Learning yang memuat media teks yang menggunakan pendekatan saintifik. PISA (2015) menyatakan bahwa konteks saintifik yang digunakan dalam media pembelajaran dapat menuntut pada munculnya pemahaman sains dan teknologi.

Pentingnya kemampuan literasi sains dimiliki seorang siswa selaras dengan makna yang terkandung dalam Al-Qur'an. Dalam surah Al-Alaq ayat 1-5 Allah telah memerintahkan kepada umat manusia untuk pentingnya memiliki kemampuan literasi dengan membaca. Adapun isi dari surah Al-Alaq ayat 1-5 tersebut adalah sebagai berikut:

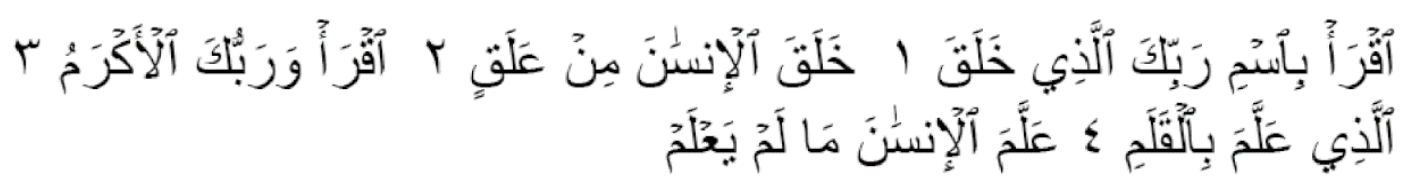

Artinya: "Bacalah dengan (menyebut) nama Tuhanmu Yang menciptakan. Dia telah menciptakan manusia dari segumpal darah. Bacalah, dan Tuhanmulah Yang Maha Pemurah. Yang mengajar (manusia) dengan perantaran kalam. Dia mengajar kepada manusia apa yang tidak diketahuinya." (Q.S. Al-Alaq: 1-5)

Makna dari surah Al-Alaq ayat 1-5 di atas menegaskan betapa pentingnya kemampuan literasi untuk dimiliki umat manusia. Makna dari uraian surah Al-Alaq ayat 1-5 memberikan pemahaman bahwa keterampilan literasi sains yang dimiliki seseorang berupa bentuk implementasi dari kegiatan membaca atau menelaah suatu ilmu guna menjadikan otak maupun hati menjadi pintu masuk utama dari ilmu pengetahuan (Said, 2016). Makna membaca menurut Quraish Shihab (1997) dipahami sebagai kegiatan menghimpun informasi dari penelitian maupun berbagai kajian sebagai sarana untuk memperoleh ilmu pengetahuan. Karena berdasarkan hasil studi dalam penelitian ini semakin baik kemampuan literasi sains yang dimiliki seseorang maka akan semakin baik pula implementasi sikap dalam sehari-harinya.

Sebelum memasuki uji hipotesis dilakukan analisis uji normalitas dan homogenitas pada data literasi sains yang merupakan uji pra-syarat hipotesis. Uji normalitas bertujuan untuk mengetahui normalitas dari distribusi data yang peroleh. Adapun hasil uji normalitas data pra-test dan post-test literasi sains yang dianalisis dengan rumus Lilifors menggunakan Microsoft Excel 365 terdapat pada Tabel 5. 
Tabel 5. Hasil Uji Normalitas Kelompok Eksperimen dan Kelompok Kontrol

\begin{tabular}{llllll}
\hline \multirow{2}{*}{ Jenis Tes } & \multicolumn{2}{c}{ Kelompok Eksperimen } & \multicolumn{2}{c}{ Kelompok Kontrol } & Keterangan \\
\cline { 2 - 5 } & Ltabel & Lhitung & Ltabel & Lhitung & \\
\hline Literasi Sains (Pra-test) & 0,1401 & 0,1329 & 0,1419 & $0,1417 \begin{array}{l}\text { Berdistribusi } \\
\text { normal }\end{array}$ \\
$\begin{array}{l}\text { Literasi Sains (Post- } \\
\text { test) }\end{array}$ & 0,1401 & 0,1124 & 0,1419 & $0,1309 \begin{array}{l}\text { Berdistribusi } \\
\text { normal }\end{array}$ \\
\hline
\end{tabular}

${ }^{*}$ Keterangan: Lnitung $<$ Ltabel (data terdistribusi normal)

Tabel 5 menginterpretasikan bahwa hasil uji normalitas data pada taraf signifikansi 0,05 dengan $L_{\text {hitung }}<L_{\text {tabel }}$. Nilai $L_{\text {hitung }}$ pada hasil pra-test dan post-test kelompok eksperimen sebesar 0,1329 dan 0,1124 dan Lnitung pada hasil pra-test dan post-test kelompok kontrol sebesar 0,1417 dan 0,1309. Sehingga nilai pra-test dan post-test literasi sains pada kelompok kontrol dan kelompok eksperimen diinterpretasikan dalam keadaan terdistribusi normal.

Setelah dilakukan uji normalitas pada data, tahap selanjutnya adalah uji homogenitas yang dilakukan untuk mengidentifikasi variansi data. Kriteria penilaian dalam uji homogenitas ialah apabila $F_{\text {hitung }}>F_{\text {tabel }}$ maka kedua data diinterpretasikan memiliki variansi yang homogen. Adapun hasil uji homogenitas data pra-test dan posttest literasi sains dari kedua kelompok sampel terdapat pada Tabel 6.

Tabel 6. Homogenitas Data Kelompok Kontrol dan Kelompok Eksperimen

\begin{tabular}{llll}
\hline Jenis Tes & F hitung & F tabel & Keterangan \\
\hline Literasi Sains (Pra-test) & 0,5599 & 0,5852 & Data Homogen \\
Literasi Sains (Post-test) & 0,5752 & 0,5852 & Data Homogen \\
\hline
\end{tabular}

${ }^{\star}$ Keterangan: $F_{\text {hitung }}<F_{\text {tabel }}$ (data homogen)

Tabel 6 merepresentasikan hasil uji homogenitas data dari kelompok eksperimen dan kontrol. Nilai pra-test dan post-test literasi sains pada kedua kelas adalah homogen karena nilai $F_{\text {hitung }}<F_{\text {tabel }}$. Dengan nilai $F_{\text {hitung }}$ sebesar 0,5599 pada pra-test literasi sains dan 0,5752 pada post-test literasi sains, sedangkan $F_{\text {tabel }}$ sebesar 0,5852.

Setelah melalui uji pra-syarat hipotesis dan diketahui data terdistribusi normal dan homogen. Tahap selanjutnya adalah dilakukan uji hipotesis menggunakan $t$ - Test: Two-Sample Assuming Equal Variances pada program Microsoft Excel 365. Dalam uji hipotesis ini bertujuan untuk mengetahui pengaruh implementasi media eXe Learning materi pewarisan sifat terhadap literasi sains siswa. Hasil analisis uji hipotesis penelitian ini terdapat pada Tabel 7.

Tabel 7. Hasil Uji Hipotesis Pengaruh Implementasi Media eXe Learning terhadap Literasi Sains

\begin{tabular}{|c|c|c|c|c|}
\hline Variabel & Kelas & t hitung & $t$ tabel & Keterangan \\
\hline Literasi Sains & $\begin{array}{l}\text { Kelas Eksperimen } \\
\text { Kelas Kontrol }\end{array}$ & 5,147 & 1,665 & Ha diterima \\
\hline
\end{tabular}

Tabel 7 merepresentasikan nilai thitung sebesar 5,147 dan nilai tabel sebesar 1,665. $\mathrm{Hal}$ ini dapat diinterpretasikan bahwa nilai thitung $>$ tabel maka $\mathrm{H}_{\mathrm{a}}$ diterima yakni terdapat perbedaan pengaruh yang signifikan pada kemampuan literasi sains siswa kelas IX 
MTs Muslimat NU Palangka Raya setelah implementasi media pembelajaran berbasis eXe Learning materi pewarisan sifat. Adanya perbedaan pengaruh yang signifikan pada penggunaan media eXe Learning terhadap literasi sains siswa sejalan dengan penelitian yang digagas oleh Muzijah, Wati, dan Mahtari (2020). Penelitiannya menyatakan bahwa eXe Learning dinilai efektif untuk diimplementasikan guna meningkatkan kemampuan literasi sains siswa. Karena penggunaan media eXe learning memiliki bahasa sifatnya komunikatif dan dapat berlangsung dua arah yang memudahkan siswa mempelajari suatu materi.

Perbedaan literasi sains siswa dengan pembelajaran yang menggunakan media eXe Learning pada kelompok eksperimen lebih besar dari literasi sains siswa dengan pembelajaran konvensional yang menggunakan media whiteboard pada kelompok kontrol. Karena dengan menggunakan media eXe Learning yang dilengkapi dengan beragam multimedia mampu menjadikan pembelajaran menjadi lebih menyenangkan dan memotivasi siswa untuk aktif dalam pembelajaran (Copriady, 2014; Sitompul, 2015).

Aspek multimedia dalam media eXe Learning juga dilengkapi dengan laboratorium virtual untuk mendukung terwujudnya indikator pemahaman konsep sains dan pemecahan masalah pada konten sains. Laboratorium virtual yang digunakan diantaranya adalah proses ekstraksi sederhana pada DNA untuk mengamati strukturnya, kemudian laboratorium virtual mengenai rekayasa genetika pada gen bakteri, dan laboratorium virtual mengenai mekanisme persilangan pada Drosophila melanogaster atau lalat buah. Laboratorium virtual yang ada dalam media eXe Learning mengajak kepada siswa untuk dapat menggunakan pemahaman sains yang telah diperoleh untuk dapat diterapkan dalam pengamatan virtual, serta bertujuan untuk memecahkan beberapa rumusan masalah yang ada pada pengamatan tersebut.

Pembelajaran dengan implementasi laboratorium virtual mampu membuat pembelajaran menjadi aktif (Putri, Sarwi, dan Akhlis, 2018). Laboratorium virtual yang ada dalam media eXe Learning juga turut mendukung adanya peningkatan kemampuan literasi sains siswa, karena laboratorium virtual mampu menyediakan inkuiri sains yang mendukung peserta didik untuk aktif menemukan dan memahami suatu permasalahan dalam konteks sains (Ismail, Permanasari, dan Setiawan, 2016). Pembelajaran dengan laboratorium virtual dalam media eXe Learning juga menjadikan pembelajaran menjadi lebih bermakna. Karena siswa dapat mengkonstruk pengetahuannya dari penemuan dan pemecahan rumusan masalah yang diamati. Pembelajaran yang bermakna penting untuk dimiliki karena menajdikan pengetahuan yang terkonstruk dapat diingat lebih lama (Aisyah, Gipayana, Djatmika, 2017). Pembelajaran bermakna hanya dapat diperoleh salah satunya melalui Inkuiri sains pada pengamatan laboratorium virtual (Ardianto \& Rubini, 2016). Dengan demikian visi literasi sains yaitu membekali siswa dengan pengetahuan konsep sains yang benar serta mampu menerapkan konsep sains pada fenomena kehidupan sehari-hari dapat tercapai. 


\section{SIMPULAN DAN SARAN}

Berdasarkan hasil penelitian ini dapat disimpulkan bahwa terdapat perbedaan pengaruh yang signifikan pada kemampuan literasi sains siswa kelas IX MTs Muslimat NU Palangka Raya setelah implementasi media pembelajaran berbasis eXe Learning materi pewarisan sifat karena diperoleh nilai thitung $>t_{\text {tabel, }}$ yaitu nilai thitung sebesar 5,147 dan nilai tabel sebesar 1,665. Penelitian lebih lanjut mengenai implementasi pembelajaran menggunakan media eXe Learning perlu dilakukan pada materi biologi lain dan diteliti pada variabel lain sehingga dapat diketahui secara luas kelebihan dan kekurangan media eXe Learning ini untuk digunakan dalam pembelajaran.

\section{UCAPAN TERIMA KASIH}

Terimakasih kepada Rektor IAIN Palangka Raya, Dekan FTIK IAIN Palangka Raya, dan Kepala Jurusan PMIPA IAIN Palangka Raya. Terimakasih kepada Kepala MTs Muslimat NU Palangka Raya yang telah memberikan ijin dan dukungan atas penelitian ini. Terimakasih kepada lbu Lilik Supatmi, S.Pd selaku guru IPA. Dan terimakasih banyak Dosen Pembimbing 1 dan 2 yakni lbu Hj. Nurul Septiana, M.Pd dan Bapak H. Mukhlis Rohmadi, M.Pd yang telah banyak membantu dalam konsultasi dan penyusunan artikel penelitian ini.

\section{RUJUKAN}

Aisyah, D. W., Gipayana, M., \& Djatmika, E. T. (2017). Mengembangkan Kebermaknaan Belajar dengan Rancangan Pembelajaran Tematik Bercirikan Quantum Teching. In Prosiding Seminar Nasional Mahasiswa Kerjasama Direktorat Jenderal Guru dan Tenaga Kependidikan Kemendikbud 2016.

Andina, E. (2011). Buku Digital dan Pengaturannya. Jurnal Aspirasi, 2(1)

Ardianto, D., \& Rubini, B. (2016). Literasi sains dan aktivitas siswa pada pembelajaran IPA terpadu tipe shared. Unnes Science Education Journal, 5(1)

Arief, M. K. (2015). Penerapan Levels of Inquiry Pada Pembelajaran IPA Tema Pemanasan Global Untuk Meningkatkan Literasi Sains. Jurnal Edusentris, 2(2).

Arisman, A. (2015). Penerapan Pembelajaran Kooperatif Tipe STAD dengan Metode Praktikum dalam Pembelajaran IPA Terpadu untuk Meningkatkan Literasi Sains Siswa. In Prosiding Seminar Nasional Fisika (E-Journal) (Vol. 4, pp. SNF2015I).

Arjunaita, A. (2020). Pendidikan Di Era Revolusi Industri 5.0. In Prosiding Seminar Nasional Program Pascasarjana Universitas PGRI Palembang.

Copriady, J. (2014). Penerapan SPBM yang Diintegrasikan dengan Program eXe Learning terhadap Motivasi Hasil Belajar Mahasiswa pada Mata Kuliah Kimia Dasar. Jurnal Pendidikan, 5(2), 95-105.

Ismail, I., Permanasari, A., \& Setiawan, W. (2016). Efektivitas Virtual Lab Berbasis STEM dalam Meningkatkan Literasi Sains Siswa Dengan Perbedaan Gender. Jurnal Inovasi Pendidikan IPA, 2(2), 190-201.

Jamil, A., Listyono, L., \& Norra, B. (2020). Pengembangan Big Book Untuk Meningkatkan High Order Thinking Skill Siswa SMP. Bioeduca: Journal of Biology Education, 2(2),

64-73. doi:http://dx.doi.org/10.21580/bioeduca.v2i2.6282 
Kurnia, F., \& Fathurohman, A. (2014). Analisis Bahan Ajar Fisika Sma Kelas XI di Kecamatan Indralaya Utara Berdasarkan Kategori Literasi Sains. Jurnal Inovasi Dan Pembelajaran Fisika, 1(1)

Kusmana, A. (2017). E-learning dalam Pembelajaran. Lentera Pendidikan: Jurnal Ilmu Tarbiyah dan Keguruan, 14(1)

Latip, A., \& Permanasari, A. (2015). Pengembangan Multimedia Pembelajaran Berbasis Literasi Sains Untuk Siswa SMP Pada Tema Teknologi. Edusains, 7(2), 160-171.

Lubis, A., \& Napitupulu, E. (2016). Pengaruh Strategi Pembelajaran Dengan Penggunaan Media Exelearning dan Komunikasi Interpersonal terhadap Hasil Belajar IPA Siswa Kelas VIII SMP Negeri di Kecamatan lima puluh. Jurnal Teknologi Informasi \& Komunikasi dalam Pendidikan, 3(2).

Machril, Sadzali Yunaifi, \& Darwin. (2015). Pengaruh Media Pembelajaran Exe (Elearning Xhtml Editor) terhadap Hasil Belajar Konstruksi Bangunan Kompetensi Keahlian Teknik Gambar Bangunan pada Siswa Kelas X SMK Negeri 5 Medan. Jurnal Education Building, 1(1)

Mukti, F. D. (2018). Integrasi Literasi Sains Dan Nilai-Nilai Akhlak di Era Globalisasi.

Abdau: Jurnal Pendidikan Madrasah Ibtidaiyah, 1(2), 318-338.

Muzijah, R., Wati, M., \& Mahtari, S. (2020). Pengembangan E-modul Menggunakan Aplikasi Exe-Learning untuk Melatih Literasi Sains. Jurnal IImiah Pendidikan Fisika, 4(2), 89-98.

Nofiana, M., \& Julianto, T. (2018). Upaya Peningkatan Literasi Sains Siswa Melalui Pembelajaran Berbasis Keunggulan Lokal. Biosfer: Jurnal Tadris Biologi, 9(1), 24-35.

Odja, A. H., \& Payu, C. S. (2014). Analisis Kemampuan Awal Literasi Sains Siswa pada Konsep IPA. Prosiding disajikan dalam Seminar Nasional Kimia (Vol. 20), Jurusan Kimia FMIPA Universitas Negeri Surabaya, Surabaya, 20 September.

OECD. (2015). PISA 2015 Draft Mathematic Framework. New York: Columbia University

Putri, S. B., Sarwi, S., \& Akhlis, I. (2018). Pembelajaran Inkuiri Terbimbing Melalui Kegiatan Lab Virtual dan Eksperimen Riil untuk Peningkatan Penguasaan Konsep dan Pengembangan Aktivitas Siswa. UPEJ Unnes Physics Education Journal, 7(1), 14-22.

Risma, M., Rahmayani, R., \& Handayani, F. (2019). Analisis konten buku teks IPA terpadu kelas VIII semester 1 ditinjau dari aspek literasi saintifik. Jurnal Eksakta Pendidikan (JEP), 3(2), 200-208.

Rohmawati, E., Widodo, W., \& Agustini, R. (2018). Membangun Kemampuan Literasi Sains Siswa Melalui Pembelajaran Berkonteks Socio-Scientific Issues Berbantuan Media Weblog. Jurnal Penelitian Pendidikan IPA, 3(1), 8-14.

Rosandi, A. K. F., Tjandrakirana, T., \& Supardi, I. (2016). Pengembangan Multimedia IPA Berbasis Flash untuk Meningkatkan Literasi Sains Siswa SMP. Prisma Sains: Jurnal Pengkajian IImu dan Pembelajaran Matematika dan IPA IKIP Mataram, 4(1), 34-40.

Said, Colle. (2016). Paradigma Pendidikan dalam Perspektif Surah Al-'Alaq Ayat 1-5. Hunafa: Jurnal Studia Islamika, 13(1)

Shihab, M. Quraish. (1997). Mujizat Alquran. Bandung: Mizan

Sitompul, H. S. (2015). Peningkatan Hasil Belajar Kimia Dan Karakter Peserta Didik Melalui Implementasi Model Problem Based Learming Dengan Media Exe Learning Di SMA Kelas X Berdasarkan Kurikulum 2013 (Doctoral dissertation, UNIMED). 
Sudirgayasa, I. G, I W. Suastra, dan N. P. Ristiati. (2014). Pengaruh Model Pembelajaran Berbasis Nature of Science (NOS) terhadap Kemampuan Aplikasi Konsep Biologi dan Pemahaman NOS Siswa dalam Pembelajaran Biologi di SMA Negeri 1 Marga. E-Journal : Program Pascasarjana Universitas Pendidikan Ganesha Program Studi Pendidikan IPA Volume 4

Sudjana, Nana. (2007). Penilaian Hasil Proses Belajar Mengajar. Bandung: Remaja Rosdakarya

Sugiyono. (2016). Metode Penelitian Kuantitatif, Kualitatif, dan R\&D. Bandung: Alfabeta.

Wibowo, T. H. (2020). Pengembangan Multimedia Interaktif Menggunakan Blended Learning Dalam Meningkatkan Kemampuan Literasi Sains Dan Self Efficacy (Doctoral dissertation, Universitas Lampung).

Yuliati, Y. (2017). Literasi Sains dalam Pembelajaran IPA. Jurnal Cakrawala Pendas, $3(2)$. 